\title{
Does inoculation with Rhizobium tropici and nitrogen fertilization increase chickpea production?
}

\section{Inoculação com Rhizobium tropici e adubação nitrogenada aumentam a produção de grão-de-bico?}

\author{
Maria Nilfa Almeida Neta ${ }^{1}$ (D), Rodinei Facco Pegoraro"*(iD), Regynaldo Arruda Sampaio ${ }^{10}$, \\ Cândido Alves da Costa' (iD), Luiz Arnaldo Fernandes ${ }^{1}$, Jessica Mendes Ferreira' ${ }^{1 D}$
}

'Universidade Federal de Minas Gerais. Montes Claros, MG, Brasil

${ }^{*}$ Corresponding author: rodinei_pegoraro@yahoo.com.br

Received in June 6, 2020 and approved in July 17, 2020

\begin{abstract}
Studies related to nitrogen fertilization and biological nitrogen fixation in the increase of chickpea production are considered scarce in tropical regions. This work aimed to evaluate the inoculation with Rhizobium tropici, and nitrogen fertilization, under irrigated tropical conditions, on the development of chickpea in low and high content of soil organic matter (SOM). The experimental design was in randomized blocks, with four replications, in a $2 \times 6$ factorial scheme. Treatments, consisted of the presence and absence of inoculation with $R$. tropici, and six $N$ doses $\left(0,25,50,75,100\right.$, and $\left.125 \mathrm{~kg} \mathrm{ha}^{-1}\right)$ in the form of urea. The study was divided into two areas with distinct contents of SOM. In the area with the lowest content of SOM (3.55 dag $\left.\mathrm{kg}^{-1}\right)$, the inoculation with $R$. tropici or the fertilization with $125 \mathrm{~kg} \mathrm{ha}^{-1} \mathrm{~N}$ increased the leaf content of nutrients $(\mathrm{N}, \mathrm{K}, \mathrm{Mg}$, and $\mathrm{P})$ and grain mass per plant, 100-grain mass, number of pods with two grains, dry mass of leaves, branches, chlorophyll index, and relative agronomic efficiency. Thus, the yield was increased in $65 \%$, compared to the control treatment, recommending the application of 100 to 125

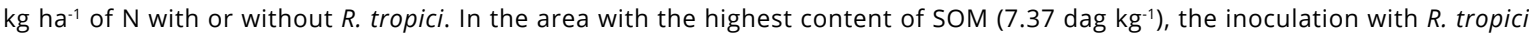
provided a higher grain mass per plants, number of pods with one gain, dry mass of leaves, total dry mass, and chlorophyll index; nitrogen fertilization increased the leaf content of $\mathrm{N}$ and the chlorophyll index, although neither factor interfered with the yield, and are not recommended. Such results indicate the dependence of the nitrogen fertilization and inoculation with Rhizobium on the natural availability of $\mathrm{N}$ in the SOM.
\end{abstract}

Index terms: Cicer arietinum L.; N doses; soil organic matter.

\begin{abstract}
RESUMO
Estudos relacionados à adubação nitrogenada e fixação biológica de nitrogênio no aumento da produção de grão-de-bico são considerados escassos em regiões tropicais. Objetivou-se avaliar a inoculação do Rhizobium tropici e doses de $\mathrm{N}$ sob condições irrigadas em região tropical nos componentes de produção e desenvolvimento do grão-de-bico, em solos com maior e menor teor de matéria orgânica (MOS). O delineamento foi em blocos ao acaso, com quatro repetições, esquema fatorial $2 \times 6$, consistindo da presença e ausência da inoculação do $R$. tropici e seis doses de $0,25,50,75,100$ e $125 \mathrm{~kg} \mathrm{ha}^{-1}$ de $\mathrm{N}$ na forma de ureia. $O$ estudo foi dividido em duas áreas com distintos teores de matéria orgânica do solo (MOS). Na área com menor teor de MOS (3.55 dag kg-1), a inoculação com $R$. tropici ou a adubação com $125 \mathrm{~kg} \mathrm{ha}^{-1}$ de $\mathrm{N}$ aumentaram os teores foliares de nutrientes ( $\mathrm{N}, \mathrm{K}, \mathrm{Mg}$ e $\mathrm{P}$ ) e a massa de grãos por planta, massa de 100 grãos, número de vagens com dois grãos, massa seca de folhas, ramos,índice de clorofila e eficiência agronômica relativa. Com isso, a produtividade foi incrementada em $65 \%$, em comparação ao tratamento testemunha, recomendando-se a aplicação de 100 a $125 \mathrm{~kg} \mathrm{ha}^{-1}$ de N com ou sem $R$. tropici. Na área com maior teor de MOS, a inoculação com R. tropici propiciou maior massa de grãos por plantas, número de vagens com um grão, massa seca de folhas, total e índice de clorofila; a adubação nitrogenada aumentou o teor foliar de $\mathrm{N}$ e o índice de clorofila, mas ambos não interferiram na produtividade, não sendo recomendadas. Tais resultados indicam a dependência do manejo da adubação nitrogenada e inoculação com Rhizobium à disponibilidade natural de $\mathrm{N}$ na MOS.
\end{abstract}

Termos para indexação: Cicer arietinum L.; doses de N; matéria orgânica do solo. 


\section{INTRODUCTION}

Chickpea (Cicer arietinum L.) is the third most cultivated grain legume in the world, with a production of 14.5 million tons and a mean grain yield of $0.96 \mathrm{t} \mathrm{ha}^{-1}(\mathrm{FAO}$, 2017). India detains $70 \%$ of world chickpea production, being the largest consumer of this crop (Icrisat, 2017). In Brazil, the development of more productive and adapted cultivars to the local climatic conditions of cultivation has allowed the increase of production. The Brazilian semi-arid region has the potential to obtain grain yields greater than 1,000 kilos per hectare (Pegoraro et al., 2018; Avelar et al., 2018; Artiaga et al., 2015). In this condition, chickpea presents a higher nutritional demand, especially for elements related to the production of biomass and grains, such as nitrogen.

Nitrogen $(\mathrm{N})$ is the main component of proteins, nucleic acids, chlorophyll, coenzymes, phytohormones, and secondary metabolites, being decisive for plant growth (Marschner, 2012; Taiz et al., 2017). Given its importance and high mobility in the soil, this element has been studied, aiming at maximizing the use efficiency through management practices that reduce losses and increase its use efficiency by plants. Ismail, Amoursy and Mousa (2017) and Khaitov and Abdiev (2018) reported the need to apply 48 and $75 \mathrm{~kg} \mathrm{ha}^{-1} \mathrm{~N}$ for higher grain yield in chickpeas in Bangladesh and Uzbekista, respectively. However, these doses of $\mathrm{N}$ vary according to the productive potential of the crop and soil characteristics, such as the organic matter content, responsible for the supply of native $\mathrm{N}$ to the plants.

The acquisition of $\mathrm{N}$ by plants via symbiotic process, either in replacement to mineral fertilization or in association can be cited as practices that can increase the efficiency of $\mathrm{N}$ use in agriculture. However, for productive chickpea cultivars, these management data are still scarce. In this crop, the biological fixation of atmospheric $\mathrm{N}$ can contribute substantially to reduce the consumption of mineral fertilizers, being able to accumulate from 80 to 120 $\mathrm{kg} \mathrm{ha}^{-1} \mathrm{~N}$ (Laranjo; Alexandre; Oliveira, 2014; Nascimento et al., 2016; Singh; Singh, 2018; Zhang et al., 2020). Singh and Singh (2018) report that the chickpea vegetable residues incorporated into the soil have a low $\mathrm{C}: \mathrm{N}$ ratio, which favors the rapid availability of $\mathrm{N}$ to subsequent crops, also favoring the availability of $\mathrm{P}$ by increasing the content of soil organic matter (SOM).

The main advantage of biological fixation lies on the natural conversion of atmospheric $\mathrm{N}_{2}$ via reaction at ambient temperature and sub-atmospheric pressure into mineral forms that are absorbable by the plants (Marschner, 2012; Zhang et al., 2020), whereas in the industrial process for the production of nitrogen fertilizer, greenhouse gases are released, demanding a great amount of non-renewable fossil fuel (Jensen; Carlsson; Hauggaard-Nielsen, 2020).

However, the formation of symbiosis between nodulating bacteria and chickpea cannot supply the nitrogen demand of the crop, requiring complementation via inorganic fertilization (Elias; Herridge, 2014; WoldeMeskel et al., 2018). In this context, the response of fertilization on yield depends on factors related to soil and plant, among them the presence of SOM and the productive potential of the cultivar, among others. Soils with a high content of organic matter present greater natural availability of $\mathrm{N}$ to plants (Liu et al., 2020; Camargo et al., 2008), interfering with the external demand for nitrogen fertilization and the symbiosis with nodulating bacteria (Marschner, 2012). Alvarez et al. (2020) reported the nitrogen mineralization capacity of organic matter as the main characteristic of the soil responsible for wheat production in the Argentine Pampas.

The elaboration of studies that comprise the ability of the chickpea crop in using the nitrogen from nodulating bacteria and nitrogen fertilization is required for the adequation of the management of this grain legume in tropical regions. In that perspective, this work aimed to evaluate the inoculation with $R$. tropici, and nitrogen fertilization, under irrigated tropical conditions, on the development of chickpea in low and high content of soil organic matter (SOM).

\section{MATERIAL AND METHODS}

The experiments were conducted in the autumnwinter period, in two years of cultivation in 2017 (April to June) and 2018 (March to June), located at the geographic coordinates $16^{\circ} 40^{\prime} 35.96^{\prime \prime} \mathrm{S}$ and $43^{\circ} 50^{\prime} 55.51^{\prime \prime} \mathrm{O}$. The climate of the region is classified as $A w$, with a dry winter and a rainy summer (Alvares et al., 2013). The climatic conditions were monitored during the conduction of the studies (Figure 1).

Both soils were classified as Haplic Cambisols (IUSS, 2015) with a medium texture. Before the implantation of the crop, soil samples were collected at a 0-20 cm depth for chemical characterization. In the area with the lowest content of SOM (in 2017), the following values were verified: organic matter: 3.55 dag $\mathrm{kg}^{-1}$; $\mathrm{pH}\left(\mathrm{H}_{2} \mathrm{O}\right): 7.6 ; 10 \mathrm{mg} \mathrm{kg}^{-1} \mathrm{~N}^{-N^{-}}{ }_{3}^{-} ; 10 \mathrm{mg} \mathrm{kg}^{-1} \mathrm{~N}^{-N_{4}}{ }_{4}^{+} ; 1.67$ $\mathrm{mg} \mathrm{kg}^{-1}$ total $\mathrm{N} ; 7.56 \mathrm{mg} \mathrm{dm}^{-3} \mathrm{P}$ (Mehlich 1 ); $177 \mathrm{mg} \mathrm{dm}^{-3}$ $\mathrm{K}$ (Mehlich 1); $7.5 \mathrm{cmol}_{\mathrm{c}} \mathrm{dm}^{-3} \mathrm{Ca} ; 1.92 \mathrm{cmol}_{\mathrm{c}} \mathrm{dm}^{-3} \mathrm{Mg}$, $0.0 \mathrm{cmol}_{\mathrm{c}} \mathrm{dm}^{-3} \mathrm{Al}(\mathrm{KCl}) ; 0.85 \mathrm{cmol}_{\mathrm{c}} \mathrm{dm}^{-3} \mathrm{H}+\mathrm{Al} ; 9.87 \mathrm{cmol}_{\mathrm{c}}$ $\mathrm{dm}^{-3} \mathrm{SB} ; 9.87 \mathrm{cmol}_{\mathrm{c}} \mathrm{dm}^{-3} \mathrm{CEC}$ (effective); $92 \%$ base saturation; $11.14 \mathrm{cmol}_{\mathrm{c}} \mathrm{dm}^{-3} \mathrm{CEC}$ (potential); this soil was 
cultivated for approximately ten years with fruit species and annual crops. In the area with the highest content of SOM (in 2018), the following chemical characteristics were obtained: $7.37 \mathrm{dag} \mathrm{kg}^{-1}$ organic matter; $\mathrm{pH}\left(\mathrm{H}_{2} \mathrm{O}\right)$ : 5.5; $60 \mathrm{mg} \mathrm{kg}^{-1} \mathrm{~N}^{-\mathrm{NO}_{3}} ; 20 \mathrm{mg} \mathrm{kg}^{-1} \mathrm{~N}^{-} \mathrm{NH}_{4}^{+} ; 2.17 \mathrm{mg} \mathrm{kg}^{-1}$ total $\mathrm{N} ; 2.93 \mathrm{mg} \mathrm{dm}^{-3} \mathrm{P}$ (Mehlich 1); $76 \mathrm{mg} \mathrm{dm}^{-3} \mathrm{~K}$ (Mehlich 1); $7.3 \mathrm{cmol}_{\mathrm{c}} \mathrm{dm}^{-3} \mathrm{Ca} ; 3.46 \mathrm{cmol}_{\mathrm{c}} \mathrm{dm}^{-3} \mathrm{Mg} ; 0.04 \mathrm{cmol}_{\mathrm{c}} \mathrm{dm}^{-3}$ $\mathrm{Al}(\mathrm{KCl}) ; 3.95 \mathrm{cmol}_{\mathrm{c}} \mathrm{dm}^{-3} \mathrm{H}+\mathrm{Al} ; 10.96 \mathrm{cmol}_{\mathrm{c}} \mathrm{dm}^{-3} \mathrm{SB} ; 11$ $\mathrm{cmol}_{\mathrm{c}} \mathrm{dm}^{-3} \mathrm{CEC}$ (effective); 73\% base saturation (V\%); $14.92 \mathrm{cmol}_{\mathrm{c}} \mathrm{dm}^{-3} \mathrm{CEC}$ (potential), and the soil laid fallow for ten years. These soils showed favorable chemical conditions for the cultivation of chickpea, however, in the area with the lowest SOM content, the $\mathrm{pH}$ was considered above of the appropriate range (5.5 to 6.5) recommended by Nascimento et al. (2016).

Both studies, the experiments were performed under randomized blocks design, with four replications, in a $2 \times 6$ factorial scheme. The first factor was represented by either the absence or presence of Rhizobium tropici SEMIA 4077, in the form of a commercial peat-based product in a 2:1 ratio (peat:inoculum), at a concentration of $1 \times 10^{9}$ UFC per gram. The second factor consisted of six $\mathrm{N}$ doses $\left(0,25,50,75,100\right.$ and $\left.125 \mathrm{~kg} \mathrm{ha}^{-1}\right)$, in the form of urea $(45 \% \mathrm{~N})$, applied thirty days after emergence (DAE) and incorporated.

Soil preparation was performed by plowing and harrowing in both areas. The chickpea cultivar used was the 'Aleppo', with grains of the Kabuli type, of semi-erect growth, and with adaptability to the semiarid region of Minas Gerais (Nascimento et al., 2014). The sowing was performed in the planting furrow, with two seeds spaced every $0.10 \mathrm{~m}$, and the thinning was performed after emergence to obtain ten plants per linear meter, spaced $0.50 \mathrm{~m}$ between rows. The plots consisted of four rows of $2 \mathrm{~m}$ long and $2 \mathrm{~m}$ wide, totaling $4 \mathrm{~m}^{2}$ of area, with $2 \mathrm{~m}^{2}$ of usable area.

Base fertilization, at sowing, was performed with the application of $110 \mathrm{~kg} \mathrm{ha}^{-1} \mathrm{P}_{2} \mathrm{O}_{5}$ (single superphosphate) and $20 \mathrm{~kg} \mathrm{ha}^{-1} \mathrm{~K}_{2} \mathrm{O}$ (potassium chloride) in the planting furrow, using the soil analysis described above to recommended fertilization (highest technological level-NT4) in bean cultivation, according to Chagas et al. (1999). The topdressing with nitrogen fertilization was performed close to the sowing row (approximately $5 \mathrm{~cm}$ far from the plants), at thirty DAE. At 30 and $50 \mathrm{DAE}$, in all plots, the following micronutrients were supplied via foliar application: $\mathrm{B}, \mathrm{Mo}$, $\mathrm{Cu}, \mathrm{Fe}$, and $\mathrm{Zn}$, at the ratio of $0.2 \%$ boric acid $\left(0.34 \mathrm{~g} \mathrm{~L}^{-1} \mathrm{~B}\right)$, $0.2 \%$ sodium molybdate $\left(0.3 \mathrm{~g} \mathrm{~L}^{-1} \mathrm{Mo}\right), 0.2 \%$ copper sulfate $\left(0.26 \mathrm{~g} \mathrm{~L}^{-1}\right.$ of $\left.\mathrm{Cu}\right), 0.2 \%$ ferrous sulfate $\left(0.38 \mathrm{~g} \mathrm{~L}^{-1} \mathrm{Fe}\right)$, and $0.2 \%$ zinc sulfate $\left(0.40 \mathrm{~g} \mathrm{~L}^{-1} \mathrm{~B}\right)$, respectively (Nascimento et al., 2016).

Phytosanitary treatments and irrigation were performed according to the need of the crop and the technical recommendations for the crop in the region (Nascimento et al., 2016). Irrigation was performed by micro-sprinklers in 2017 and with a conventional sprinkler systemin 2018, with an irrigation shift of four days. The manual control of weeds was performed whenever necessary. Plant health treatments and irrigation were carried out according to crop needs and technical recommendations for the crop in the region, as indicated by Nascimento (2016). A micro-spray irrigation system was used, with irrigation frequency of every four days.

Lowest content of SOM

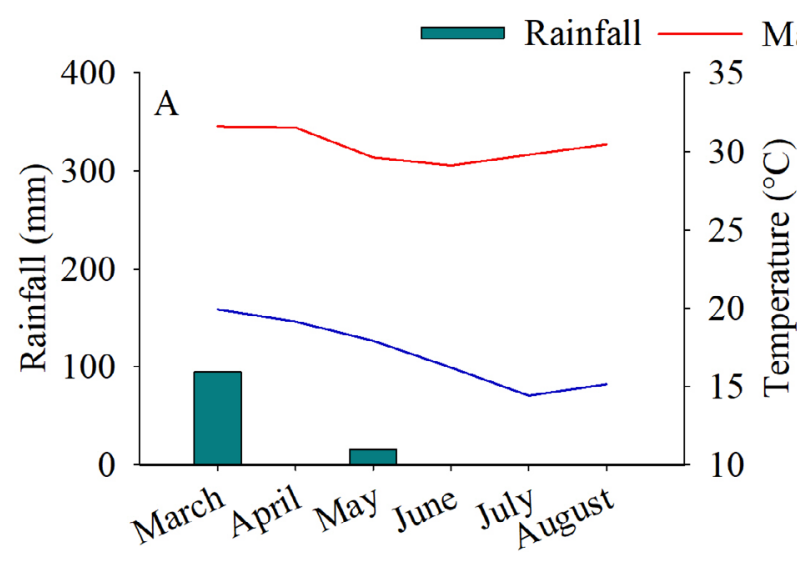

\section{Highest content of SOM} Maximum - Minimum

Figure 1: Rainfall, maximum and minimum temperature during chickpea cultivation for the area with the lowest in 2017 (A) and highest in 2018 (B) content of SOM, according to the data by National Institute of Meteorology (INMET, 2019). 
At flowering, which occurred at 70 DAE, the total chlorophyll content was performed using a chlorophyll meter (SPAD-502) through twenty measurements on the main leaflets of the central plants of each useful plot. At this moment, the collection of twenty leaflets was also performed, which were stored and taken to a forced-air circulation oven at $65{ }^{\circ} \mathrm{C}$ until reaching constant mass. Afterward, the leaflets were ground in a Wiley mill with a $02 \mathrm{~mm}$ mesh, homogenized, and sampled for the determination of the $\mathrm{N}$ contents, according to the Kjeldahl method (Bataglia et al., 1983), and $\mathrm{P}, \mathrm{K}, \mathrm{Ca}, \mathrm{Mg}$, and $\mathrm{Na}$, determined by nitricperchloric digestion (Tedesco; Volkweiss; Bohnen, 1995).

At the end of the crop cycle (100 DAE), the following variables were evaluated in the ten central plants of each plot: plant height $(\mathrm{cm})$, dry mass weight $(\mathrm{g}$ per plant) of botanic structure: leaves (LDM), branches (BDM), and total (TDM), as well as the 100-grain mass (G100), grains per plant (GP), number of pods with one grain (NP1), two grains (NP2), and total (NPT), yield in $\mathrm{kg} \mathrm{ha}^{-1}$, harvest index (HI) in \% ((seed weight/shoot biomass) $x$ 100) and agronomic efficiency, expressed by the following Equation 1:

$A E=\frac{Y t a-Y t i}{D T a}$

In which:

$\mathrm{AE}=$ Agronomic efficiency in $\mathrm{kg}$ of grains per $\mathrm{kg}$ of nutrient applied

Yta $=$ Yield of the treatment fertilized with $\mathrm{N}\left(\mathrm{kg} \mathrm{ha}^{-1}\right)$

Yti $=$ Yield of the control treatment $\left(\mathrm{kg} \mathrm{ha}^{-1}\right)$

$\mathrm{DTa}=$ Dose in the treatment fertilized with $\mathrm{N}\left(\mathrm{kg} \mathrm{ha}^{-1}\right)$
The data were subjected to analysis of variance. Afterward, according to the significance $(\mathrm{p} \leq 0.05)$, the $\mathrm{t}$-test was used for the qualitative factors, and the adjustments with regression models were performed for the quantitative factors, selected based on the significance of the regression coefficients and the potential to explain the biological phenomenon. Statistical analyses were performed using R software (R Development Core Team, 2013). For the main production components (G100, GP, TDM, and NPT) and the yield, the grouping analysis was also performed (dendrograms) using the un weighted pair-group average method (UPGMA) and distance metric of the Euclidean distance (non-standardized), as proposed by Klikocka and Tatarczak (2015) for the evaluation of production components in field experiments.

\section{RESULTS AND DISCUSSION}

\section{Plant development and nutrient contents -area with the lowest content of SOM.}

The plant characteristics were not influenced by the interaction between inoculation and doses of $\mathrm{N}$. The inoculation with $R$. tropici did not interfere with the CI, Height, G100, NP1, TNP, and HI features (Table1), which obtained the following means: $45,102 \mathrm{~cm}, 29 \mathrm{~g}, 28$, and 39 , respectively. These means were similar to those obtained by Pegoraro et al. (2018) after phosphate fertilization and inoculation with $R$. tropici in the chickpea cultivar 'Aleppo'. However, the height obtained in the present study was considered superior to that described by Artiaga et al. (2015). These authors observed heights from 33 to 66

Table 1: Chlorophyll index (Cl), height $(H)$, 100-mass grain (G100), grain mass per plant (GP), number of pods with one grain (NP1), two grains (NP2), and total (TNP), dry mass of leaves (LDM), branches (BDM), and total dry mass (TDM), yield, harvest index $(\mathrm{HI})$, agronomic efficiency (AE), leaf contents of nitrogen $(\mathrm{N})$, potassium $(\mathrm{K})$, calcium $(\mathrm{Ca})$, magnesium (Mg), sodium (Na), and phosphorus (P) of the chickpea cultivar Aleppo with and without inoculation with $R$. tropici.

\begin{tabular}{|c|c|c|c|c|c|c|c|c|c|}
\hline $\mathrm{RIZ}$ & $\mathrm{Cl}$ & $\mathrm{H}$ & G100 & GP & NP1 & NP2 & TNP & LDM & BDM \\
\hline & & $\mathrm{cm}$ & g & g & & & & \multicolumn{2}{|c|}{ g per plant } \\
\hline With & $44.68^{\mathrm{ns}}$ & $101.14^{\mathrm{ns}}$ & $29.02^{\mathrm{ns}}$ & $9.63 \mathrm{a}$ & $31.79^{\mathrm{ns}}$ & $3.37 \mathrm{a}$ & $44.29 \mathrm{~ns}$ & $7.07 \mathrm{a}$ & $21.60 \mathrm{a}$ \\
\hline Without & $44.52^{\mathrm{ns}}$ & $103.48^{n s}$ & $28.83^{n s}$ & $6.54 \mathrm{~b}$ & $23.36^{\mathrm{ns}}$ & $2.04 \mathrm{~b}$ & $34.60 \mathrm{~ns}$ & $5.29 \mathrm{~b}$ & $17.47 \mathrm{~b}$ \\
\hline \multirow[t]{3}{*}{ CV (\%) } & 9.60 & 9.90 & 9.95 & 39.34 & 35.60 & 74.08 & 32.91 & 24.68 & 30.47 \\
\hline & TDM & Yield & $\mathrm{HI}$ & $A E$ & $\mathrm{~N}$ & K & $\mathrm{Ca}$ & $\mathrm{Mg}$ & $\mathrm{Na}$ \\
\hline & g per plant & $\mathrm{t} \mathrm{ha}^{-1}$ & & & \multicolumn{5}{|c|}{ - } \\
\hline With & $34.56 a$ & $1.93 a$ & $26.21^{\mathrm{ns}}$ & $12.33 \mathrm{a}$ & $33.06 \mathrm{~b}$ & $20.10^{\mathrm{ns}}$ & $8.09^{\mathrm{ns}}$ & $3.54^{\text {ns }}$ & $0.26 \mathrm{a}$ \\
\hline Without & $27.33 \mathrm{~b}$ & $1.30 \mathrm{~b}$ & $25.12^{\mathrm{ns}}$ & $4.85 \mathrm{~b}$ & $39.83 a$ & $21.54^{\mathrm{ns}}$ & $8.76^{\mathrm{ns}}$ & $3.37^{\text {ns }}$ & $0.21 \mathrm{~b}$ \\
\hline CV (\%) & 39.91 & 39.92 & 31.39 & 137.83 & 21.96 & 21.01 & 16.83 & 39.33 & 39.33 \\
\hline
\end{tabular}

Means followed by the same lowercase letter in the column do not differ from each other by the F-test. 
$\mathrm{cm}$ when evaluating thirteen chickpea genotypes of distinct origins and two commercial cultivars, 'Cícero' and 'IAC Marrocos', in dry land farming conditions.

The inoculation with $R$. tropici increased the NP2, GP, LDM, BDM, TDM, and the Yield by 40, 32, 25, 19, 21, and $33 \%$, respectively, compared to the absence of inoculation (Table 1). The increase in shoot biomass and yield (Table 1) by the inoculation with $R$. tropici was justified by several possible positive effects on phytohormones production, nutrient absorption and increased photosynthetic activity of the plant. $R$. tropici in the roots, through the nitrogenase enzyme complex, catalyzes the reduction reaction of atmospheric $\mathrm{N}_{2}$ in the plants into $\mathrm{NH}_{3}^{+}$, which is converted into organic forms (amides or ureides) released in the xylem and transported to the shoot part, where they are catabolized into ammonium $\left(\mathrm{NH}_{4}^{+}\right)$by the plants (Taiz et al., 2017). Gopalakrishnan et al. (2018), studying three diazotrophic bacteria (native to India) in chickpea inoculation, also observed an increase in the number of nodules, as well as a higher dry mass of shoot and root.

The production of phytohormones and the greater availability of nutrients in plants that form a symbiosis with nitrogen-fixing bacteria also improved their growth and yield (Singh; Singh, 2018; Laranjo; Alexandre; Oliveira, 2014; Marschner, 2012). This phenomenon may have occurred with the chickpea inoculated with $R$. tropici.

The inoculation of $R$. tropici it may also have favored the growth and grain yield of chickpeas by stimulating the photosynthetic activity of plants. Beneficial effects have been reported by enhanced growth and development of photosynthetic organs and the rate of photosynthates accumulation (Moinuddin et al., 2014). Thus, nodulating plants may have greater photosynthetic activity due to the increased demand for carbon compounds consumed by the symbiotic bacteria for $\mathrm{N}_{2}$ fixation (Kaschuk et al., 2012), this metabolic alteration may favor plant growth and grain yield in legumes.

The agronomic efficiency was increased by $66 \%$ in the treatment with $R$. tropici (Table 1), which indicates a positive effect of inoculation on chickpea production, even after the application of $\mathrm{N}$ doses. In Ethiopia, through which Wolde-Meskel et al. (2018) obtained a positive response of the inoculation with Mesorhizobium ciceri on chickpea yield $\left(2.0 \mathrm{tha}^{-1}\right)$, compared to the control treatment $\left(1.6 \mathrm{t} \mathrm{ha}^{-1}\right)$ without inoculation. Emphasizing the importance of the inoculation with nodulating bacteria in chickpea in order to obtain higher profitability and quality of grains (Gopalakrishnan et al., 2018; Zhang et al., 2020).

The inoculation with $R$. tropici increased the leaf content of $\mathrm{Na}(19 \%)$ and reduced the content of $\mathrm{N}$ by $17 \%$, but interfered with the contents of $\mathrm{K}, \mathrm{Ca}$, and
$\mathrm{Mg}$, compared to the absence of the inoculant (Table 1). The higher biomass production in the shoot part of the inoculated plants possibly provided a dilution effect of $\mathrm{N}$ in the plant tissue compared to the absence of inoculation, as demonstrated by Marles (2017). The increase in carbohydrate production is not proportionally followed by the content of minerals, that is, the nutrient contents of the plant may decrease without causing a lower grain yield (Marles, 2017; Briat et al., 2020).

The $\mathrm{N}$ doses increased the chlorophyll index (Figure 2B), obtaining an increment of 0.06 in the CLO for each kilogram of $\mathrm{N}$ added, indicating a potential increase of growth and production of cultivated plants. Increases in the chlorophyll content favor the photosynthetic rates at low light intensities, resulting in a healthy plant with a higher yield (Joshi et al., 2019; Gu et al., 2017). Higher doses of $\mathrm{N}$ also incremented the G100 and NP2 (Figure 2C, 2E). Each kilogram of $\mathrm{N}$ added contributed to the increase of $0.03 \mathrm{~g}$ in the 100 -grain mass and 0.22 pods with two grains.

The height, NP1, and NPT were not influenced by the increment in the doses of $\mathrm{N}$ (Figure 2A and 2E). The dose of $125 \mathrm{~kg} \mathrm{ha}^{-1}$ of $\mathrm{N}$ incremented the dry mass of leaves, branches, grains, and the total dry mass (Figure 2D), with $7,23,10$, and $36 \mathrm{~g}$ per plant, respectively. The application of $125 \mathrm{~kg} \mathrm{ha}^{-1} \mathrm{~N}$ with or without $R$. tropici provided the maximum production values of $2.09 \mathrm{t} \mathrm{ha}^{-1}$ grains (Figure $2 \mathrm{~F})$. These results indicate a greater importance of the factor doses of $\mathrm{N}$ for the increase of grain production in soil with lower content of organic matter, and that the application of higher doses of $\mathrm{N}$ can minimize the positive effect of nodulating bacteria in the production of chickpea. This yield was considered superior to the world average of $0.96 \mathrm{t} \mathrm{ha}^{-1}$ (FAO, 2017), and close to the $2.71 \mathrm{t} \mathrm{ha}^{-1}$ obtained by Pegoraro et al. (2018) in the northern region of Minas Gerais.

The recommended dose of $125 \mathrm{~kg} \mathrm{ha}^{-1} \mathrm{~N}$ for maximum grain production was considered high compared to studies carried out in other countries, but it is similar when compared to recommendations made for other leguminous crops in Brazil, such as beans, where the doses vary from 40 to $120 \mathrm{~kg} \mathrm{ha}^{-1}$, according to the technological level adopted. Ismail, Amoursy and Mousa (2017) and Khaitov and Abdiev (2018) reported the need to apply 48 and $75 \mathrm{~kg} \mathrm{ha}^{-1} \mathrm{~N}$ for higher grain yield in chickpeas in Bangladesh and Uzbekista, respectively. While, Rani and Krishna (2016) found no difference in grain yield using doses of 20, 30 and $40 \mathrm{~kg} \mathrm{ha}^{-1} \mathrm{~N}$ in India. The greater need for nitrogen fertilization observed in this crop (Figure 2F) may be related to the lower natural availability of nitrogen in the soil, as described in the material and methods. 

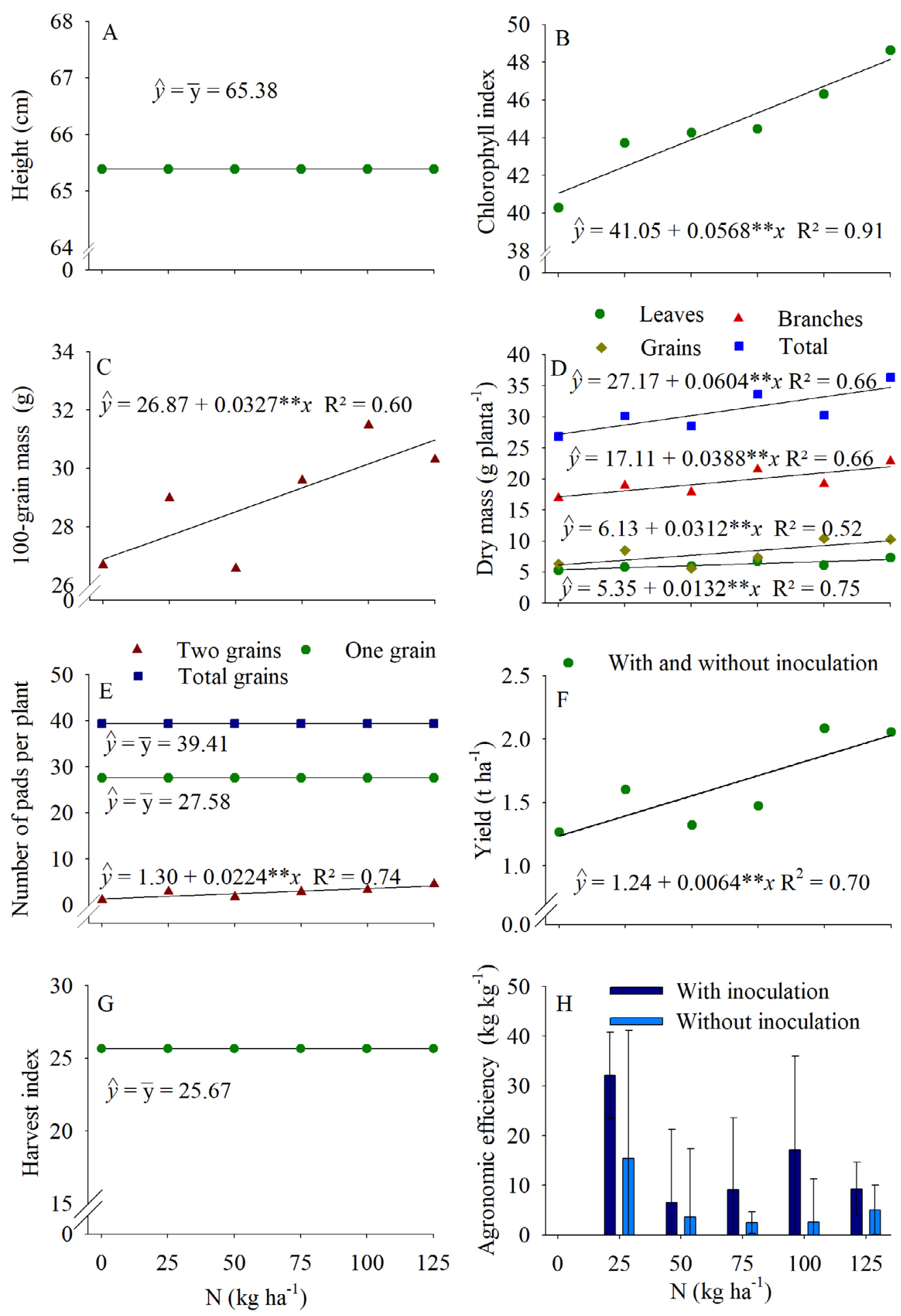

Figure 2: Height(A), chlorophyll index (B), 100-grain mass(C), dry mass of leaves, branches, grains, and total dry mass (D), number of pads with one, two, and total grains $(E)$, yield $(F)$, harvest index $(G)$, and agronomic efficiency $(\mathrm{H})$ of chickpea under $\mathrm{N}$ doses. 
The leaf contents of N, P (with inoculation), K, and $\mathrm{Mg}$ were incremented with the growing doses of $\mathrm{N}$ (Figure 3A, 3B, and 3C). The maximum contents of these nutrients corresponded to $41.45 ; 5.25 ; 23.60$, and $4.40 \mathrm{~g} \mathrm{~kg}^{-1}$, respectively, at the dose of $125 \mathrm{~kg} \mathrm{ha}^{-1} \mathrm{~N}$. With that, it is suggested that a synergistic effect of nitrogen fertilization with urea in the absorption of these macronutrients by chickpea plants is suggested (Briat et al., 2020). However, nitrogen fertilization did not interfere with the contents of $\mathrm{Ca}$, with a mean of $8.42 \mathrm{~g} \mathrm{~kg}^{-1}$ (Figure 3B), and reduced the leaf contents of $\mathrm{Na}$ in the treatment with $R$. tropici (Figure 3D). Indicating the attenuation of sodium in the plant caused by inoculation (Abdiev et al., 2019).

The content of $\mathrm{P}$ was influenced by the interaction between inoculation versus doses of $\mathrm{N}$, being lower on the leaves of the inoculated plants, and at the doses 0,25 , and $50 \mathrm{~kg} \mathrm{ha}^{-1} \mathrm{~N}$ (Figure 3C). However, the highest content of $\mathrm{P}$ was obtained in the presence of $R$. tropici at the dose of $125 \mathrm{~kg} \mathrm{ha}^{-1} \mathrm{~N}$ (Figure 3C). The performance of nodulation and $\mathrm{N}_{2}$ fixation depends on the properties of the soil and the nutrients that it contains (Briat et al., 2020), especially those nutrients with direct involvement in the structure and metabolic function of the microbial cell (Marschner, 2012). P is demanded in larger amounts by plants that associate with bacteria since there is greater ATP production for the action of the nitrogenase enzyme and the development of nodules. In the condition of greater availability of $\mathrm{N}$ and the presence of $R$. tropici, the photosynthetic activity of the plants may have been stimulated, due to the increased demand for carbon compounds consumed by the symbiotic bacteria for $\mathrm{N}_{2}$ fixation (Kaschuk et al., 2012), stimulating the absorption of $P$ by the plants and the grain yield in chickpea. The higher is nodulation the higher is the allocation of $\mathrm{P}$ in the roots of the plants (Kuang et al., 2005; Valentine; Kleinert; Benedito, 2017). This can explain the lower leaf contents of $P$ after the inoculation with $R$. tropici, at the lowest $\mathrm{N}$ doses (Figure 3C).
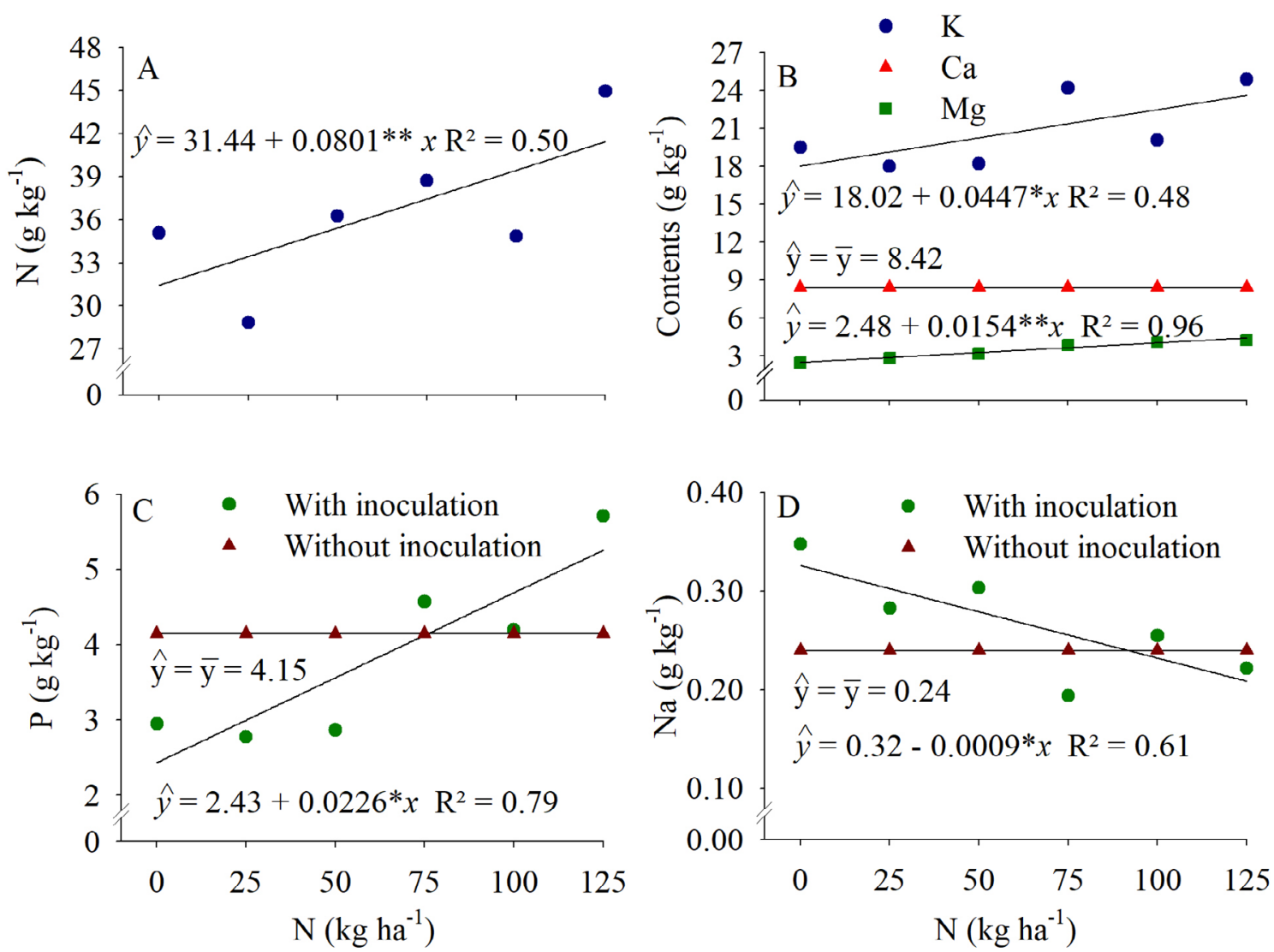

Figure 3: Contents of nitrogen (A), potassium, calcium, magnesium (B), phosphorus (C), and sodium (D) of chickpea under $\mathrm{N}$ doses. 
Through the unweighted pair-group average method (UPGMA) it was possible to identify three classes of fertilization response: 100 and $125 \mathrm{~kg} \mathrm{ha}^{-1} \mathrm{~N}$ (high response), 75 and $25 \mathrm{~kg} \mathrm{ha}^{-1} \mathrm{~N}$ (average response), and 50 and $0 \mathrm{~kg} \mathrm{ha}^{-1} \mathrm{~N}$ (low response). The height of the Y-axis for each group identifies this amplitude (Figure 4A). The three grouped classes complement the analysis of variance (Figure 2) for relating the highest productions of total and grain dry mass, 100 -grain mass, and yield, with the 100 and $125 \mathrm{~kg} \mathrm{ha}^{-1} \mathrm{~N}$. In the multivariate analysis, with the data reorganized in matrices (Figure 4B), it was also possible to identify the strong positive relationship (above 0.8 ) of the highest doses (100 and $125 \mathrm{~kg} \mathrm{ha}^{-1}$ $\mathrm{N}$ ), and the negative relationship (inferior a -0.7) of the lowest doses (50 and $0 \mathrm{~kg} \mathrm{ha}^{-1}$ ) with these components of production and yield.

\section{Plant development and nutrient contents -area with the highest content of SOM}

There was no interaction between the inoculation factors and doses of $\mathrm{N}$ for all evaluated characteristics. Isolated effect of the inoculation with $R$. tropici increased the GP, NP1, DML, and DMT (Table 2) by $27.07,26.78,20.93 \%$, and $16.26 \%$, respectively, compared to the absence of inoculation. Reinforcing the greater effect of $R$. tropici on the production of grain mass per plant. The higher content of organic matter in the soil may have increased the bacterial population, contributing to the symbiosis of $R$. tropici with the roots favoring the performance of these characteristics of chickpeas. However, this effect was limited, as inoculation did not interfere with the CI, Height,
G100, NPT, BDM, and Yield (Table 2). Indicating the greater natural capacity of this soil to provide adequate conditions for grain yield.

The absence of inoculation with $R$. tropici provided the highest leaf contents of $\mathrm{N}(9 \%), \mathrm{P}(11 \%)$, and $\mathrm{Ca}(15 \%)$ (Table 2). Contrarily to what was verified by Abdiev et al. (2019) with chickpea, with the highest contents of $\mathrm{N}, \mathrm{P}$, and $\mathrm{K}$ on roots and leaves when in the presence of inoculation.

The addition of $\mathrm{N}$ doses increased the chlorophyll index and the content of $\mathrm{N}$ in the chickpea leaves, with means of 51 and $48 \mathrm{~g} \mathrm{~kg}^{-1}$, respectively, at the $125 \mathrm{~kg} \mathrm{ha}^{-1}$ $\mathrm{N}$ (Figure 5B,5J), and it did not change the height, G100,GP, and the leaf contents of $\mathrm{P}, \mathrm{K}, \mathrm{Ca}$, and $\mathrm{Mg}$ (Figure 5A, 5C, 5D and 5J).The higher chlorophyll production and absorption of $\mathrm{N}$ at the highest doses applied did not imply directly on greater plant growth and G100, indicating the luxury absorption of $\mathrm{N}$ by the chickpea, besides the adequate supply of native $\mathrm{N}$ to the plants, at the lowest doses applied. This indicates a greater capacity of this soil with a higher SOM content in providing native $\mathrm{N}$ for chickpeas. Ciclot et al. (2017) report that the SOM nitrogen mineralization rate in the arable layer $(0.30 \mathrm{~m})$ ranges from 0.13 to $1.10 \mathrm{~kg} \mathrm{ha}^{-1}$ day $^{-1} \mathrm{~N}$ in soils in France. These authors describe a positive correlation between the mineralization rate and the SOM content, indicating a substantial increase in the availability of $\mathrm{N}$ for plants in soils with a higher SOM content. In tropical soils it is believed that these rates are higher, however, if we consider the mineralization of 1 $\mathrm{kg} \mathrm{ha}^{-1}$ day $^{-1} \mathrm{~N}$ it would be possible to supply the demand for chickpeas in the soil with higher SOM content.
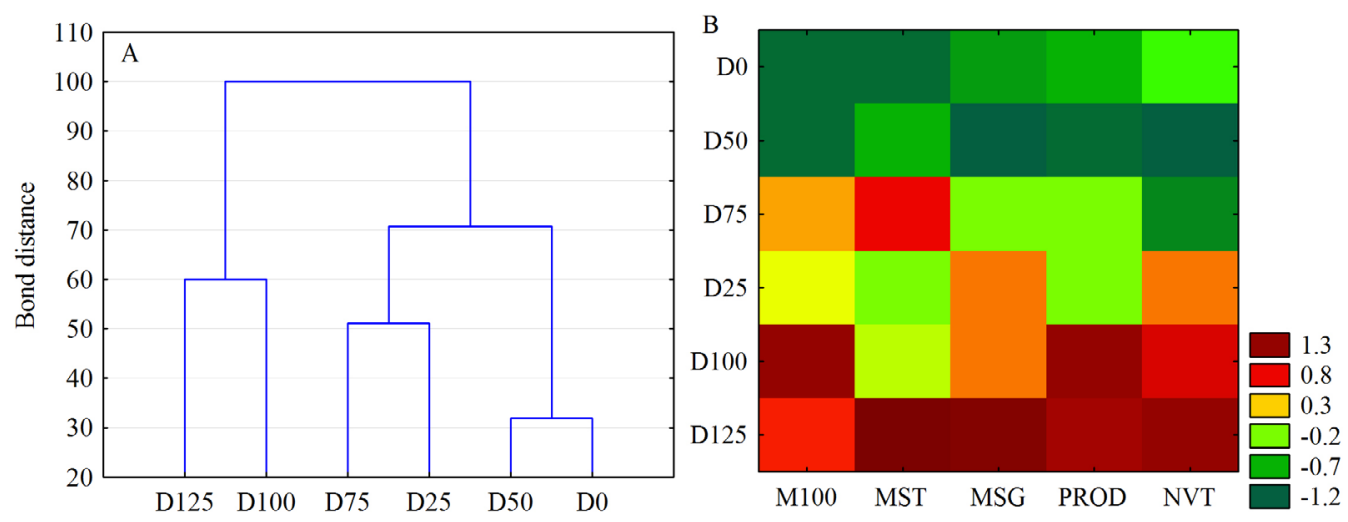

Figure 4: Dendrograms with multivariate analysis of A (UPGMA method) and B groupings (multivariate cluster analysis) for the main chickpea production components (G100 - 100-grain mass, DMT- total dry mass, GP-grain dry mass, NPT- total number of pods, and - yield) after fertilization with doses of N: D0 (0 kg ha-1), D25 (25 kg ha-1), D50 (50 kg ha-1), D75 (75 kg ha-1), D100 (100 kg ha-1), and $125\left(125 \mathrm{~kg} \mathrm{ha}^{-1}\right)$. 
Table 2: Chlorophyll index (Cl), height (H), 100-grain mass (G100), grain mass per plant (GP), number of pods with one grain (NP1), total number of pods (TNP), dry mass of leaves (LDM), branches (BDM), total dry mass (TDM), yield, harvest index $(\mathrm{HI})$, agronomic efficiency $(\mathrm{AE})$, and leaf contents of nitrogen $(\mathrm{N})$, phosphorus $(\mathrm{P})$, potassium (K), calcium (Ca), magnesium (Mg), and sodium ( $\mathrm{Na}$ ) of the chickpea cultivar 'Aleppo' with and without inoculation with R. tropici (RIZ).

\begin{tabular}{|c|c|c|c|c|c|c|c|c|c|c|c|c|c|}
\hline $\mathrm{RIZ}$ & $\mathrm{Cl}$ & $\mathrm{H}$ & G100 & GP & NP1 & \multicolumn{2}{|c|}{ TNP } & NP2 & LDM & BDM & \multicolumn{2}{|c|}{ TDM } & \multirow{2}{*}{$\begin{array}{l}\text { Yield } \\
\text { t ha- }^{-1}\end{array}$} \\
\hline & & $\mathrm{cm}$ & g & $g$ & & & & & \multicolumn{4}{|c|}{-------g per plant------- } & \\
\hline With & $46.71^{\text {ns }}$ & $77.71^{\text {ns }}$ & $38.39^{\text {ns }}$ & $25.60 a$ & $51.15 a$ & \multicolumn{2}{|c|}{$69.85^{\text {ns }}$} & $9.34 a$ & $13.90 a$ & $36.20^{\text {ns }}$ & & & $1.61^{\mathrm{ns}}$ \\
\hline Without & $48.59^{\text {ns }}$ & $81.82^{\text {ns }}$ & $38.16^{\mathrm{ns}}$ & $18.67 \mathrm{~b}$ & $37.45 b$ & \multicolumn{2}{|c|}{$51.11^{\mathrm{ns}}$} & $6.82 b$ & $10.99 b$ & $34.57^{\text {ns }}$ & & & $1.96^{\text {ns }}$ \\
\hline CV (\%) & 9.18 & 15.07 & 6.00 & 39.21 & 41.97 & \multicolumn{2}{|c|}{37.18} & 40.88 & 26.92 & 26.45 & & & 34.35 \\
\hline RIZ & $\mathrm{HI}$ & \multicolumn{2}{|c|}{$\mathrm{AE}$} & N & & K & $\mathrm{Ca}$ & \multicolumn{2}{|c|}{ IVIg } & \multicolumn{2}{|r|}{$\mathrm{Na}$} \\
\hline & $\%$ & \multicolumn{2}{|c|}{$\mathrm{kg} \mathrm{kg}^{-1}$} & & & & & $-g \mathrm{~kg}$ & 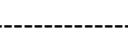 & & & & \\
\hline With & $29.86 \mathrm{~ns}$ & \multicolumn{2}{|c|}{$3.06^{\mathrm{ns}}$} & $44.23 \mathrm{~b}$ & \multicolumn{2}{|c|}{$3.20 \mathrm{~b}$} & \multicolumn{2}{|c|}{$16.38^{\mathrm{ns}}$} & $8.52 b$ & \multicolumn{2}{|c|}{$4.37^{\mathrm{ns}}$} & \multicolumn{2}{|c|}{$0.31 \mathrm{~ns}$} \\
\hline Without & $26.82^{n s}$ & 7.0 & & $48.47 \mathrm{a}$ & \multicolumn{2}{|c|}{$3.59 \mathrm{a}$} & \multicolumn{2}{|c|}{$16.22^{\mathrm{ns}}$} & $9.96 a$ & \multicolumn{2}{|c|}{$3.65^{\mathrm{ns}}$} & \multicolumn{2}{|c|}{0.29 ns } \\
\hline CV (\%) & 27.44 & \multicolumn{2}{|c|}{180.48} & 7.51 & \multicolumn{2}{|c|}{17.81} & \multicolumn{2}{|c|}{13.79} & 18.51 & \multicolumn{2}{|c|}{57.29} & & 48 \\
\hline
\end{tabular}

Means followed by the same lowercase letter in the column dot not differ from each other by the F-test.

The mean chickpea yield after the application of $\mathrm{N}$ doses corresponded to $1.78 \mathrm{t} \mathrm{ha}^{-1}$ (Figure 5F), which is above those obtained in other countries, such as India (0.91 tha $\left.{ }^{-1}\right)$, Uzbekistan $\left(1.46 \mathrm{tha}^{-1}\right)$, Ethiopia $\left(1.67 \mathrm{tha}^{-1}\right)$, and Australia (1.22 $\mathrm{t} \mathrm{ha}^{-1}$ ) (FAO, 2017). According to Rani and Krishna (2016), in India, the application of $\mathrm{N}$ doses $\left(20,30\right.$, and $\left.40 \mathrm{~kg} \mathrm{ha}^{-1}\right)$ did not interfere with grain yield, which reinforces the ability of these plants in using native $\mathrm{N}$ in the soil or provided via symbiosis. Soares et al. (2016), studying the cultivation of common beans, reported that $20 \mathrm{~kg} \mathrm{ha}^{-1}$ of $\mathrm{N}$ at sowing favored root growth and higher nodulation when compared to superior doses, suggesting that lower $\mathrm{N}$ doses can favor the initial development of vegetable species.

The $\mathrm{N}$ doses did not increment the harvest index (IC) and the agronomic efficiency (EA), and their means corresponded to $28.34 \%$ and 5.04, respectively (Figure 5G and 5H), indicating that $28.34 \%$ of the biomass accumulated in the shoot part was converted into grains. The IC and the EA refer to the ability of the plant to produce grains according to its growth and availability of nutrients via fertilization. In this context, the inexistence of alterations in grain production after the use of the highest $\mathrm{N}$ doses was observed, corroborating with the condition of adequate nutritional supply in the plant at lower $\mathrm{N}$ doses. The highest agronomic efficiency occurs when higher productions are obtained at lower $\mathrm{N}$ doses (Leal et al., 2019).

In this study, the application of Rhizobium spp. and the $\mathrm{N}$ doses did not interfere with grain production, possibly as a consequence of the high natural soil fertility especially associated with the high content of mineral $\mathrm{N}$, total $\mathrm{N}$ (NT), and soil organic matter, attributes that contribute to biological activity, providing greater availability of mineral $\mathrm{N}$ in the soil solution and higher diversity of nodulating bacteria in the soil (Marschner, 2012).

In this condition, there is a higher amount of mineral and organic $\mathrm{N}$ in the labile fraction of the soil, converted into ammonium and nitrate, released by the action of decomposing microorganisms (Liu et al., 2020; Camargo et al., 2008). Elias and Herridge (2014), in an assessment on chickpea cultivation in Australia, observed a low efficiency of this vegetable species in forming a symbiosis with native nitrogen-fixing bacteria the first years of cultivation, although this phenomenon was minimized after the use of inoculants with a greater populational abundance of Rhizobium, reinforcing the importance of the fixation of atmospheric $\mathrm{N}$ in increasing chickpea production and the subsequent crops.

In the analysis of the unweighted pair group method (UPGMA), it was possible to observe isolated behaviors, with a higher amplitude, at the doses of 125 and $0 \mathrm{~kg} \mathrm{ha}^{-1}$ $\mathrm{N}$ for the production components (Figure 6A). The 0 $\mathrm{kg} \mathrm{ha}^{-1} \mathrm{~N}$ was responsible for the obtainment of higher positive relationships (above 1.0) with the DMT, NPT, and GP, whereas the $125 \mathrm{~kg} \mathrm{ha}^{-1}$ dose was responsible for a negative relationship (below -1.0) with the yield and production components (Figure 6B), characterizing the adequate supply of $\mathrm{N}$ for chickpea production at the lowest dose used. 

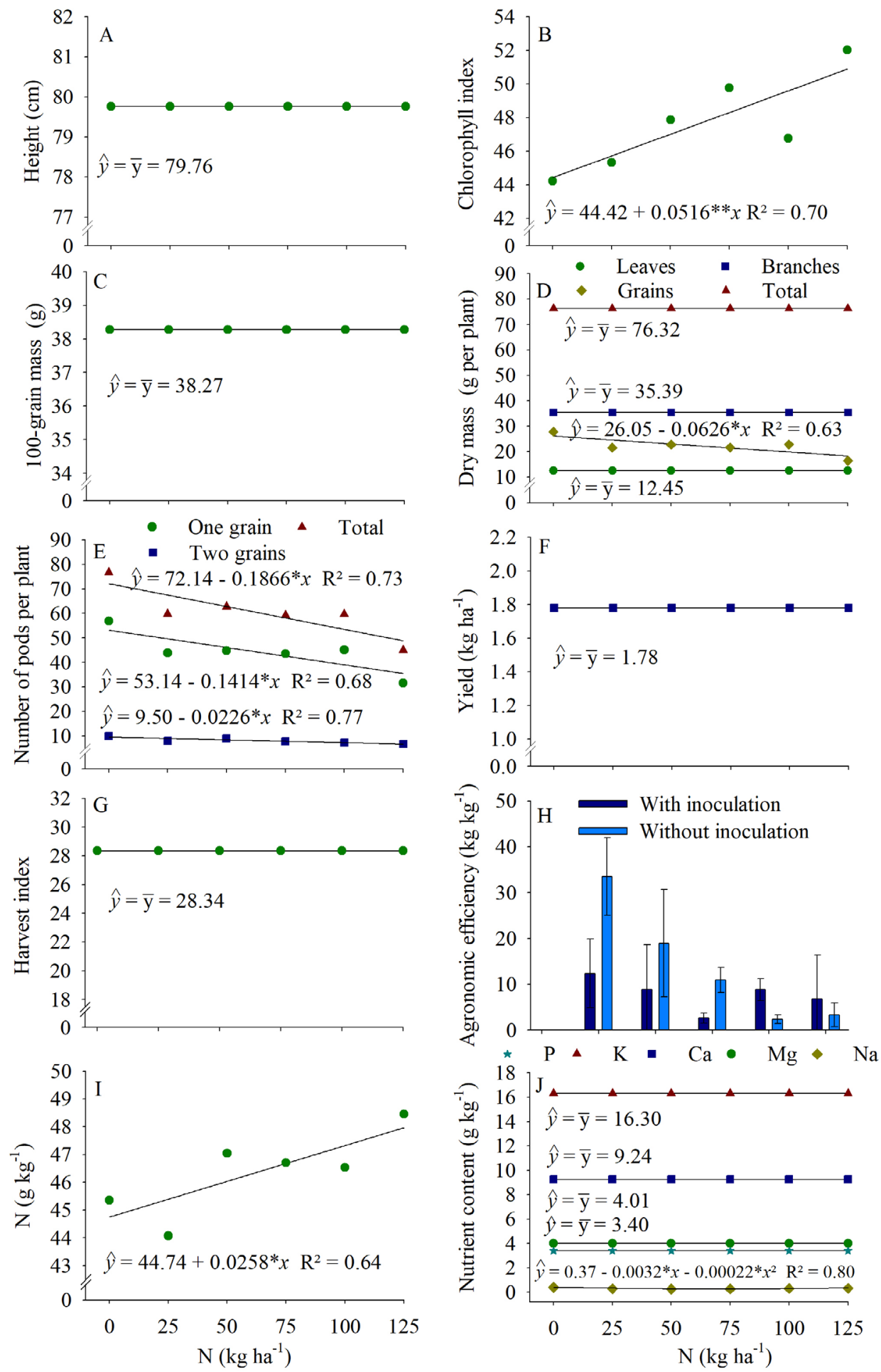

Figure 5: Height (A), chlorophyll index (B), 100-grain mass (C), dry mass of leaves, branches, seeds, and total dry mass (D), number of pods with one, two, and total grains $(E)$, yield $(F)$, harvest index $(G)$, agronomic efficiency $(H)$, leaf content of $\mathrm{N}(\mathrm{I})$, and leaf contents of phosphorus, potassium, calcium, magnesium, and sodium (J) of chickpea under $\mathrm{N}$ doses. 

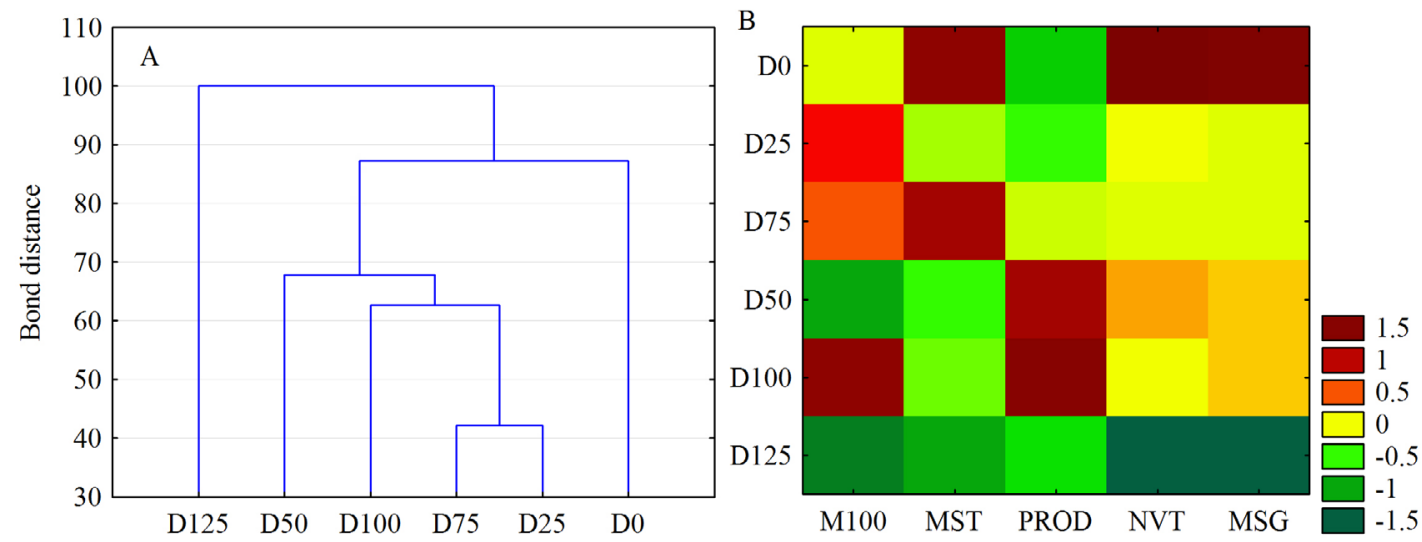

Figure 6: Dendrograms with multivariate analysis of A (UPGMA method) and B groupings (multivariate cluster analysis) for the main chickpea production components (G100-100-grain mass, DMT- total dry mass, GP- grain dry mass, NPT- total number of pod sand- yield) after fertilization with doses of N: D0 (0 kg ha-1), D25 (25 kg ha-1), D50 (50 kg ha-1), D75 (75 kg ha-1), D100 (100 kg ha-1), and $125\left(125 \mathrm{~kg} \mathrm{ha}^{-1}\right)$.

In summary, this study obtained a positive effect of the inoculation with Rhizobium and nitrogen fertilization in the increase of chickpea production in the soil with lower natural availability of $\mathrm{N}$, whereas in soils with a higher content of organic matter the production responses are less expressive, which can be attributed to the high mineralization ability of the organic fraction of the soil due to the tropical conditions of cultivation.

\section{CONCLUSIONS}

In the soil with the lowest content of organic matter, the inoculation with $R$. tropici increases the biomass of the shoot part and the chickpea yield and does not interfere with the IC. In this condition, the application of 100 to $125 \mathrm{~kg} \mathrm{ha}^{-1} \mathrm{~N}$ provides the maximum yield of $2.09 \mathrm{tha}^{-1}$ and the relative chickpea agronomic efficiency of $21.6 \%$. In the soil with the highest contents of organic matter, the inoculation with $R$. tropici increased the biomass of the shoot part and does not interfere with chickpea yield. Likewise, the $\mathrm{N}$ doses increase the chlorophyll index but do not interfere with the remaining production components and chickpea yield.

\section{ACKNOWLEDGEMENTS}

The authors thank the Foundation for Research Support of the State of Minas Gerais (FAPEMIG), the Brazilian National Council for Scientific and Technological Development (CNPq), the Pro-Rectory Research of Universidade Federal de Minas Gerais (PRPq -UFMG), and the Brazilian Coordination for the Improvement of
Higher Education Personnel (CAPES; Financial Code 001) for financial support to this research project and grating of scholarships.

\section{REFERENCES}

ABDIEV, A. et al. Growth, nutrient uptake and yield parameters of chickpea (Cicer arietinum L.) enhance by Rhizobium and Azotobacter inoculations in saline soil. Journal of Plant Nutrition, 42(20):2703-2714, 2019.

ALVARES, C. A. et al. Köppen's climate classification map for Brazil. Meteorologische Zeitschrift, 22(6):711-728, 2013.

ALVAREZ, R. et al. Using a nitrogen mineralization index will improve soil productivity rating by artificial neural networks. Archives of Agronomy and Soil Science, 66(4):517-531, 2020.

ARTIAGA, O. P. et al. Avaliação de genótipos de grão de bico em cultivo de sequeiro nas condições de Cerrado. Revista Brasileira Ciências Agrárias, 10(1):102-109, 2015.

AVELAR, R. I. S. et al. Production and quality of chickpea seeds in different sowing and harvest periods. Journal of Seed Science, 40(2):155-164, 2018.

BATAGLIA, O. C. et al. Methods of chemical analysis of plants. Campinas: Instituto Agronômico, 1983. 48p.

BRIAT, J. F. et al. Reappraisal of the central role of soil nutrient availability in nutrient management in light of recent advances in plant nutrition at crop and molecular levels. European Journal of Agronomy, 116:e126069, 2020. 
CAMARGO, F. A. O. et al. Nitrogênio orgânico do solo. In: SANTOS, G. A. et al. Fundamentos da matéria orgânica do solo: Ecossistemas tropicais e subtropicais. $2^{\text {a }}$ Ed. Porto Alegre: Metropole, 2008, p.87-97.

CHAGAS, J. M. et al. Feijão. In: RIBEIRO, A. C. et al. (Ed.) Recomendações para o uso de corretivos e fertilizantes em Minas Gerais: $5^{a}$ aproximação. Viçosa, MG: Comissão de Fertilidade do Solo do Estado de Minas Gerais, 1999. p.306-307.

CLIVOT, H. et al. Quantifying in situ and modeling net nitrogen mineralization from soil organic matter in arable cropping systems. Soil Biology and Biochemistry, 111:44-59. 2017.

ELIAS, N. V.; HERRIDGE, D. F. Crop-available water and agronomic management, rather than nitrogen supply, primarily determine grain yield of commercial chickpea in northern New South Wales. Crop and Pasture Science, 65(5):442-452, 2014.

FOOD AND AGRICULTURE ORGANIZATION OF THE UNITED NATIONS - FAO. FAOSTAT. Food and agriculture data. 2017. Available in:<http://faostat3. fao.org/faostatgateway/go/to/home/E>. Access in: JUL.10. 2018.

GOPALAKRISHNAN, S. et al. Influence of diazotrophic bacteria on nodulation, nitrogen fixation, growth promotion and yield traits in five cultivars of chickpea. Biocatalysis and Aricultural Biotechnology, 15:35-42, 2018.

$\mathrm{GU}$, J. et al. Photosynthetic properties and potentials for improvement of photosynthesis in pale green leaf rice under high light conditions. Frontiers in Plant Science, 8:1082, 2017.

INSTITUTO NACIONAL DE METEOROLOGIA - INMET, Dados meteorológicos de estações automáticas. 2019. Available in: <http://www.inmet.gov.br/portal/>. Access in: December 20, 2019.

INTERNATIONAL CROPS RESEARCH INSTITUTE FOR THE SEMIARID TROPICS - ICRISAT. Chickpea. 2017. Available in: <http://exploreit.icrisat.org/profile/Chickpea/232>.Access in: June, 02, 2019.

INTERNATIONAL UNION OF SOIL SCIENCE WORKING - IUSS, World Reference Base for Soil Resources (WRB).2015. Available in: < https://www.iuss.org/world-of-soils/>. Access in: October 12. 2019.

ISMAIL, M. M.; AMOURSY, A. H. M. E. D.; MOUSA, A. E. Effect of organic and inorganic $\mathrm{N}$ fertilizeron growth and yield of chickpea (Cicer arietinum L.) grown on sandy soil using
${ }^{15} \mathrm{~N}$ tracer. Bangladesh Journal of Botany, 46(1):155-161, 2017.

JENSEN, E. S.; CARLSSON, G.; HAUGGAARD-NIELSEN, H. Intercropping of grain legumes and cereals improves the use of soil $\mathrm{N}$ resources and reduces the requirement for synthetic fertilizer N: A global-scale analysis. Agronomy for Sustainable Development, 40(1):1-9, 2020.

JOSHI, D. et al. Impacts of bioinoculants Pseudomonas jesenii MP1 and Rhodococcus qingshengii S10107 on chickpea (Cicer arietinum L.) yield and soil nitrogen status. Pedosphere, 29(3):388-399, 2019.

KHAITOV, B.; ABDIEV, A. Performance of chickpea (Cicer arietinum L.) to bio-fertilizer and nitrogen application in arid condition. Journal of Plant Nutrition, 41(15):19801987, 2018.

KASCHUK, G. et al. Photosynthetic adaptation of soybean due to varying effectiveness of $\mathrm{N}_{2}$ fixation by two distinct Bradyrhizobium japonicum strains. Environmental and Experimental Botany, 76:1-6, 2012.

KLIKOCKA, H.; TATARCZAK, A. The use of cluster analysis to evaluate yield and yield components of spring barley in a two-variable field experiment. International Journal of Agriculture and Statistical Science, 11(1):35-42, 2015.

KUANG, R. B. et al. Phosphorus and nitrogen interactions in field-grown soybean as related to genetic attributes of root morphological and nodular traits. Journal of Integrative Plant Biology, 47(5):549-559, 2005.

LARANJO, M.; ALEXANDRE, A.; OLIVEIRA, S. Legume growthpromoting rhizobia: An overview on the Mesorhizobium genus. Microbiological research, 169(1):2-17, 2014.

LEAL, F. T. et al. Use efficiency and responsivity to nitrogen of common bean cultivars. Ciência e Agrotecnologia, 43:e004919, 2019.

LIU, K. et al. Intensifying crop rotations with pulse crops enhances system productivity and soil organic carbon in semi-arid environments. Field Crops Research, 248:107657, 2020.

MARLES, R. J. Mineral nutrient composition of vegetables, fruits and grains: The context of reports of apparent historical declines. Journal of Food Composition and Analysis, 56:93-103, 2017.

MARSCHNER, P. Marschner's mineral nutrition of higher plants. Amsterdã, Holanda: 3.ed. Academic press. v.89. 2012, 649p. 
MOINUDDIN, D. T. et al. Use of $\mathrm{N}$ and $\mathrm{P}$ biofertilizers together with phosphorus fertilizer Improves growth and physiological attributes of chickpea. Global Journal of Agriculture and Agricultural Sciences, 2(3):168-174. 2014.

NASCIMENTO, W. M. et al. BRS Aleppo: grão-de-bico. Maior tolerância a fungos de solo. Brasília; Anápolis: Embrapa Hortaliças, Boletim Técnico. 4p. 2014.

NASCIMENTO, W. M. de et al. Grão-de-bico. Hortaliças Leguminosas. Brasília, DF: Empresa Brasileira de Pesquisa Agropecuária, 89-118p, 2016.

PEGORARO, R. F. et al. Chickpea production and soil chemical attributes after phosphorus and molybdenum fertilization. Ciência e Agrotecnologia, 42(5):474-483, 2018.

RANI, B. S.; KRISHNA, T. G. Response of chickpea (Cicer arietinum $\mathrm{L}$.) varieties to nitrogen on a calcareous vertisols. Indian Journal of Agricultural Research, 50(3):278-281, 2016.

R DEVELOPMENT CORE TEAM. R: A language and environment for statistical computing. R Foundation for Statistical Computing, Vienna, Austria: 2013. Available in: <http://www.r-project.org>. Access in: February15. 2020.
SINGH, Z.; SINGH, G. Role of Rhizobium in chickpea (Cicer arietinum) production: A review. Agricultural Reviews, 39(1):31-39, 2018.

SOARES, B. L. et al. Agronomic and economic efficiency of common-bean inoculation with rhizobia and mineral nitrogen fertilization. Revista Brasileira de Ciência do Solo, 40:e0150235, 2016.

TAIZ, L. et al. Fisiologia e desenvolvimento vegetal. 6.ed. Porto Alegre, Artmed Editora, 2017. 858p.

TEDESCO, M. J.; VOLKWEISS, S. J.; BOHNEN, H. Análise de solo, plantas e outros materiais. Porto Alegre: UFRGS, 1995. $188 p$.

VAlentine, A. J.; KLEINERT, A.; BEnEdito, V. A. Adaptive strategies for nitrogen metabolism in phosphate deficient legume nodules. Plant Science, 256:46-52, 2017.

WOLDE-MESKEL, E. et al. Additive yield response of chickpea (Cicer arietinum L.) to Rhizobium inoculation and phosphorus fertilizer across mall holder farms in Ethiopia. Agriculture, Ecosystems \& Environment, 261:144-152, 2018.

ZHANG, J. et al. Biogeographic distribution of chickpea rhizobia in the world. In: ZHANG, J. et al. Molecular Aspects of Plant Beneficial Microbes in Agriculture. Amsterdã, Holanda: Academic press, 2020, p.235-239. 